Research article

\title{
A SURVEY OF DEFORMED WING VIRUS AND ACUTE BEE PARALYSIS VIRUS IN HONEY BEE COLONIES FROM SERBIA USING REAL-TIME RT-PCR
}

SIMEUNOVIĆ Predrag ${ }^{1 *}$, STEVANOVIĆ Jevrosima ${ }^{1}$, VIDANOVIĆ Dejan ${ }^{2}$, NIŠAVIĆ Jakov ${ }^{3}$, RADOVIĆ Dejan ${ }^{4}$, STANIŠIĆ Ljubodrag ${ }^{1}$, STANIMIROVIĆ Zoran $^{1}$

${ }^{1}$ Department of Biology, Faculty of Veterinary Medicine, University of Belgrade, Bul. Oslobodjenja 18, Belgrade, Serbia; ${ }^{2}$ Veterinary Specialist Institute "Kraljevo", Zicka 34, Kraljevo, Serbia; ${ }^{3}$ Department of Microbiology, Faculty of Veterinary Medicine, University of Belgrade, Bul. Oslobodjenja 18, Belgrade, Serbia; ${ }^{4}$ Faculty of Biology, University of Belgrade, Studentski trg 16, Belgrade, Serbia.

(Received 27 December 2013; Accepted 27 January 2014)

\begin{abstract}
In this study 55 honey bee colonies from different Serbian regions were monitored for the presence of Deformed Wing Virus (DWV) and Acute Bee Paralysis Virus (ABPV) using TaqMan-based real-time RT-PCR assay. The results revealed the presence of DWV in each sampling location, and ABPV in 10 out of 11 apiaries. High frequency of DWV (76.4\%) and ABPV (61.8\%) positive samples in asymptomatic colonies can be the consequence of inefficient and postponed Varroa treatment concerning the role of this mite in the transmission and activation of honey bee viruses. The real-time RTPCR technique described in this paper is proved to be the most reliable method for this kind of investigation.
\end{abstract}

Key words: DWV, ABPV, Varroa destructor, Serbian apiaries

\section{INTRODUCTION}

The honey bee Apis mellifera L. can be affected by various pathogens including numerous viruses, bacteria (Paenibacillus larvae, Melissococcus plutonius), fungi (Nosema spp., Ascosphaera apis), and parasitic mites (Varroa destructor, Acarapis woodi, Tropilaelaps spp.). Bee viruses affect bee morphology, physiology, and behavior and have been often linked with weakening and dying colonies [1]. So far, more than 18 different viruses have been identified and described in honey bee colonies [2,3]. Most of known bee viruses exist and co-exist in individuals or colonies causing unapparent and persistent infections [46]. However, due to widespread of $V$. destructor as a virus-transmitting ectoparasite, two viruses are of growing interest: Deformed wing virus (DWV) and Acute bee paralysis virus (ABPV).

DWV is one of the viruses mostly related to colony losses $[3,7]$. DWV is a $30 \mathrm{~nm}$

\footnotetext{
*Corresponding author: e-mail: simeunovicp@vet.bg.ac.rs
} 
icosahedral particle consisting of a single, positive strand RNA genome [8], typical for iflaviruses, a genus of the family Iflaviridae, within the order Picornavirales $[9,10]$. As widely and globally distributed, DWV is the most studied of all honeybee viruses [4,11-18]. DWV has been detected in adult bees, their pupae and larvae [19], as well as in Varroa mites [12] and Tropilaelaps mercedesae [20]. Transmitted vertically by queens and drones [21-23] or horizontally trough larval food [24] DWV causes benign, symptomless infections. However, transmission of DWV to pupae via $V$. destructor that acts as both a mechanical and biological vector is considered to be crucial in the manifestation of the morphological changes in adult bees [25]. Bees with typical signs of the overt DWV infection - deformed wings, shortened and bloated abdomen and miscolouring [26], are not viable and their lifespan is less than $67 \mathrm{~h}$ after emergence [25]. Furthermore, the viral replication and subsequently high enough virus titer in the mites prior to transmission are substantial for the induction of an apparent DWV infection [27]. Hence, the higher the number of DWV-transmitting mites and consequently the number of deformed bees, the greater the chances for fatal DWV infection and colony collapse [28].

ABPV has a geographical distribution similar to that of $A$. mellifera and usually exist in a low concentration as a covert infection [29,30]. Together with Israeli acute paralysis virus (IAPV) and Kashmir bee virus (KBV), ABPV is a putative member of the genus Apavirus, family Dicistroviridae, within the order Picornavirales [9,10]. Common feature of viruses belonging to Dicistroviridae is a bicistronic, single-stranded RNA genome, consisting of two open reading frames (ORFs). In the wake of $V$. destructor in Europe and its establishment as a virus-transmitting parasite, the number of overt ABPV infections in severely Varroa-infested colonies has rapidly increased [11,13,31,32]. This phenomenon is related with the finding of ABPV extreme virulence when directly injected into the bee haemolymph causes bee mortality within a few days [16]. Nevertheless, the exact role of the Varroa mite in the increase in ABPV virulence still remains elusive. Due to rapid progression from paralysis to death in individual bees, effects of covert ABPV infections, including trembling and inability to fly, are rarely visible at colony level [16]. Two surveys conducted in Germany [3,33] revealed a significant relation between ABPV infection in autumn and colony mortality in the following winter season. Since ABPV can frequently be detected in bees from both asymptomatic and collapsing colonies $[12,13,18]$, it is difficult to define the influence of ABPV infection on colony mortality. Different techniques have been used in the detection of bee viruses, including indirect fluorescent-antibody analysis, agarose gel immunodiffusion (AGID), enzyme-linked immunosorbent assay (ELISA), reverse transcription-PCR (RT-PCR) and real-time RTPCR [34-39]. Development of real-time RT-PCR assays has significantly increased the sensitivity and specificity in the detection of honey bee viruses [40].

During the past several years, beekeepers in Serbia frequently report colony depopulation, morphological changes of adult bees (dark color and deformed wings), symptoms of central nervous system disorder (trembling and inability to fly), or sudden collapse of entire colonies. When it comes to bee pathogens related with colony decline in Serbia, there are recent investigations of Nosema sp. [41,42] and $V$. destructor [43,44]. The presence of bee viruses in Serbia was first reported by Kulinčević et al. [45] when four honey bee viruses were identified: ABPV, Egypt bee virus, J strain (EBV), Cloudy wing 
virus (CWV) and Black queen cell virus (BQCV). However, these viruses were detected using only serological methods and in bees sampled from one location (Belgrade). Also, the results from a recent study [46] showed the presence of five viruses in honey bee samples from Serbia. The mentioned investigation encompassed only apiaries from northern Serbia and the detection of bee viruses was based upon the conventional RTPCR assay. Surveys conducted in France, Austria, Hungary and Slovenia revealed that ABPV and DWV viruses are prevalent in European honey bees, present in $37-70 \%$ and $70-97 \%$ of bee samples, respectively $[12,13,15,47]$. Thus, survey of DWV and ABPV in Serbia is important for the assessment of their impacts on beekeeping in this country. The goal of this study was to investigate the occurrence and prevalence of DWV and ABPV in asymptomatic honey bee colonies from different regions of Serbia. TaqMan one-step real-time RT-PCR is used because of its capability to detect a small amount of viral copies in samples from apparently healthy colonies. This helps to increase the throughput, reduces the chance of carry-over contamination and eliminates post-PCR processing as a potential source of error [48].

\section{MATERIAL AND METHODS}

\section{Honey bee samples}

Bee samples were collected from 55 seemingly healthy colonies located at 11 apiaries ( 5 colonies per apiary) distributed in northern, southern, eastern, western and central Serbia (Figure 1). Colonies considered being valid for honey production were randomly selected within each apiary and checked for the absence of clinical signs of viral infections. Samples consisting of approximately 100 worker bees were taken from each colony during the second half of September. Samplings were done by licensed veterinarians. Live bees were collected with sterile single-use vessels, placed into sterile test tubes, immediately stored in dry ice, transported to the laboratory and stored at $-20^{\circ} \mathrm{C}$ until processed.

\section{Sample preparation and RNA extraction}

From each sample, 30 randomly selected bees were crushed and homogenized in a sterile mortar in the presence of $5 \mathrm{~mL}$ PBS solution. After homogenization, purification of samples was conducted by centrifugation for $15 \mathrm{~min}$ at $5,000 \times g$ and $140 \mu \mathrm{L}$ of supernatant was collected and used for RNA extraction. Total RNA was extracted using ZR Viral RNA Kit ${ }^{\mathrm{TM}}$ (Zymo Research, Orange, CA) according to manufacturer's recommendations. Extracted RNA was quantified by spectrophotometry and an average of $2 \mu \mathrm{g}$ was used for single real-time RT-PCR reaction. Isolates were stored at $-80{ }^{\circ} \mathrm{C}$ until use.

\section{Real-time RT-PCR assay}

To achieve the best optimization of the reaction, the real-time RT-PCR assay was conducted with positive controls for DWV and ABPV, kindly provided by the Veterinary Institute "Kraljevo" (Serbia). The positive controls were obtained after conventional 
RT-PCR and proved to be DWV and ABPV by sequencing. The primer pairs and PCR program used for RT-PCR were those recommended by the "French Agency for Food, Environmental and Occupational Health \& Safety" (ANSES) [49].

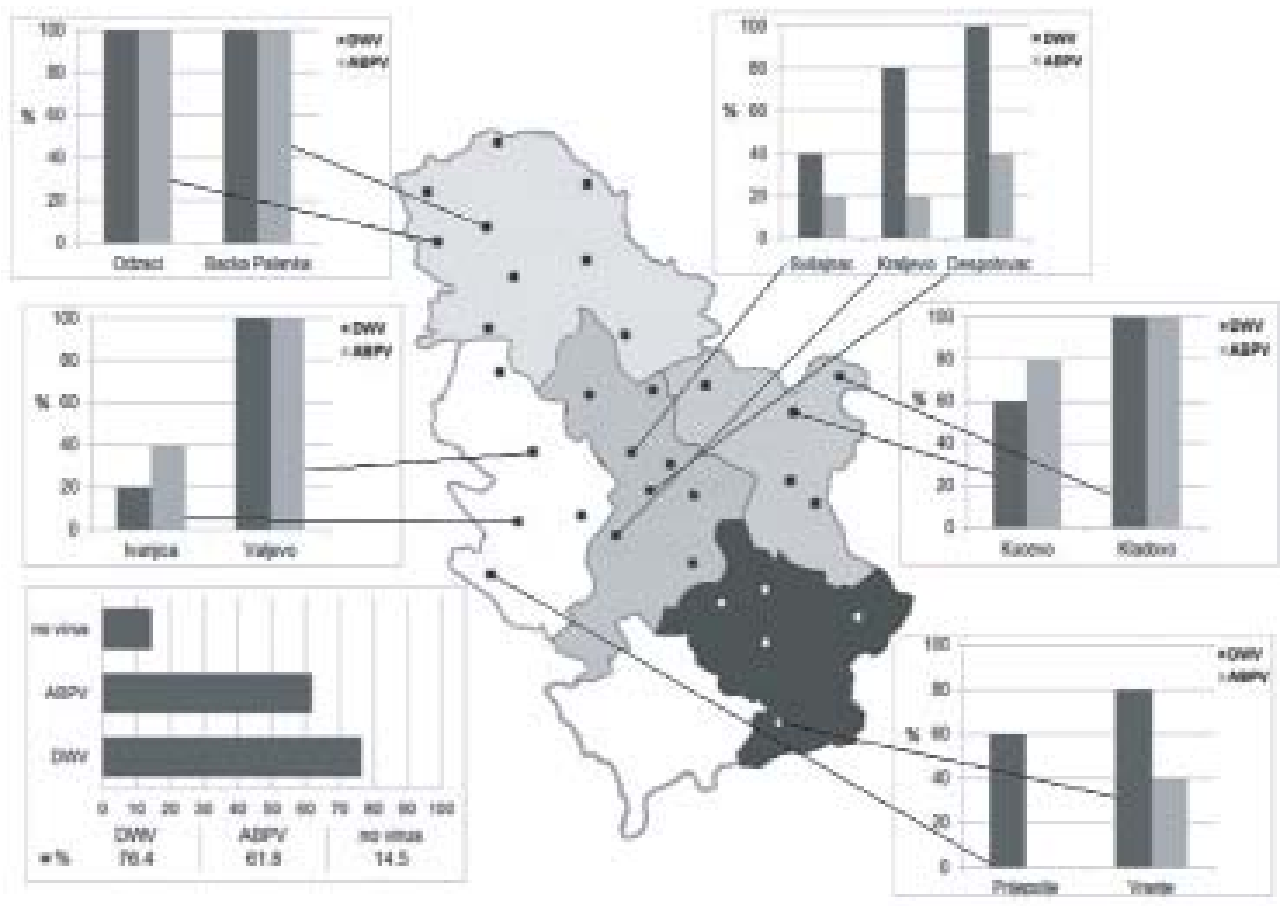

Figure 1. Occurrence and distribution pattern of DWV and ABPV among sampling location in Serbia.

All real-time RT-PCR reactions were performed on Rotor-Gene Q 5plex (Qiagen, Germany) and the presence of DWV and ABPV in bee samples were tested in a separate single step reaction using the Rotor-Gene Probe RT-PCR Kit (Qiagen, Germany). The primer pairs and probes (Table 1) were selected based upon the previous report of Chantawannakul et al. [14]. Both primers and TaqMan probes were obtained by Eurofins MWG Operon (Germany). The 5'-terminal reporter dye for each probe was 6-carboxyfluorescin (FAM) and the 3'- quencher was tetra-methylcarboxyrhodamine (TAMRA). After several trials, the final concentration of $800 \mathrm{nM}$ for primers and 400 $\mathrm{nM}$ for probes in the reaction were affirmed as most appropriate. All analyses were carried out in a $25 \mu \mathrm{L}$ reaction volume containing: $12.5 \mu \mathrm{L}$ of $2 \mathrm{x}$ Rotor-Gene Probe RT-PCR Master Mix (Qiagen, Germany), $0.8 \mu \mathrm{M}$ of each primer (one pair of primers per reaction), $0.4 \mu \mathrm{M}$ of each probe, $0.25 \mu$ l Rotor-Gene RT Mix (Qiagen, Germany), RNAse-free water and $2 \mathrm{ng}$ of RNA template. The thermal cycling profile included a reverse transcription step of $50^{\circ} \mathrm{C}$ for $10 \mathrm{~min}$, followed by an initial activation step of $95^{\circ} \mathrm{C}$ for $5 \mathrm{~min}$ and 45 cycles of denaturation $\left(95^{\circ} \mathrm{C}\right.$ for $\left.15 \mathrm{sec}\right)$, primer annealing $\left(50^{\circ} \mathrm{C}\right.$ for $30 \mathrm{sec})$ and DNA extension $\left(72^{\circ} \mathrm{C}\right.$ for $\left.30 \mathrm{sec}\right)$. Fluorescence was acquired during the elongation step. Negative controls (no template) were included in each reaction run. 
Table 1. Sequence of the TaqMan primers and probes used for the detection of DWV and ABPV

\begin{tabular}{|c|c|c|c|}
\hline Primer/Probe & Target & Sequence (5'-3') & Reference \\
\hline $\begin{array}{l}\text { DWV958F } \\
\text { DWV9711R } \\
\text { DWV9627T }\end{array}$ & $\begin{array}{l}\text { Deformed } \\
\text { wing virus }\end{array}$ & $\begin{array}{l}\text { CCTGGACAAGGTCTCGGTAGAA } \\
\text { ATTCAGGACCCCACCCAAAT } \\
\text { CATGCTCGAGGATTGGGTCGTCGT }\end{array}$ & $\begin{array}{l}\text { Chantawannakul } \\
\text { et al. (2006) }\end{array}$ \\
\hline $\begin{array}{l}\text { APV95F } \\
\text { APV159R } \\
\text { APV121T }\end{array}$ & $\begin{array}{l}\text { Acute bee } \\
\text { paralysis } \\
\text { virus }\end{array}$ & $\begin{array}{l}\text { TCCTATATCGACGACGAAAGACAA } \\
\text { GCGCTTTAATTCCATCCAATTGA } \\
\text { TTTCCCCGGACTTGAC }\end{array}$ & $\begin{array}{l}\text { Chantawannakul } \\
\text { et al. (2006) }\end{array}$ \\
\hline
\end{tabular}

F- forward primer; R - reverse primer; T - probe. Probes consist of oligonucleotides with a 5'-reporter dye (FAM, 6-carboxy-Xuorescein) and a 3'-quencher (TAMRA, tetra-methylcarboxyrhodamine)

\section{RESULTS}

DWV was found to be more prevalent than ABPV. Among all analysed bee samples, $76.4 \%$ was positive for DWV and $61.8 \%$ for ABPV. Although both viruses were affirmed in all monitored Serbian regions, only DWV was detected in every sampled apiary (Figure 1, Table 2). Figure 1 shows the distribution and prevalence of DWV and ABPV in the sampled locations. The northern region of Serbia, represented by sampling locations Odzaci and Backa Palanka, showed the highest frequency of DWV and ABPV, as both were found in $100 \%$ of samples. Also, both viruses were found in all samples from locations Valjevo (Western Serbia) and Kladovo (Eastern Serbia). ABPV nucleic acid was not detected in any of the samples from the westernmost sampled location (Prijepolje).

Altogether, at least one of the investigated viruses was detected in $85.5 \%$ of samples (in 47 out of 55 colonies). Simultaneous infections with DWV and ABPV were present in $50.9 \%$ of samples (28/55 colonies). Single infections with either DWV or ABPV were detected in $23.6 \%$ (13/55 colonies) and $9.1 \%$ (5/55 colonies) of samples, respectively. Only $14.5 \%(8 / 55)$ of sampled colonies were negative for the presence of DWV and ABPV by real-time RT-PCR assay (Table 2).

Table 2. Overall frequencies of DWV and ABPV infections found in examined honey bee samples from Serbia

\begin{tabular}{cccc}
\hline $\begin{array}{c}\text { Single or } \\
\text { simultaneous } \\
\text { infections }\end{array}$ & Type of infection & $\begin{array}{c}\text { No. of } \\
\text { samples }\end{array}$ & $\%$ \\
\hline Single & DWV & 13 & 23.6 \\
& ABPV & 5 & 9.1 \\
Simultaneous & DWV, ABPV & 28 & 50.9 \\
& & & \\
\multirow{2}{*}{ Total } & DWV & 42 & 76.4 \\
& ABPV & 34 & 61.8 \\
& No viruses & 8 & 14.5 \\
\hline
\end{tabular}


The real-time RT-PCR assay with the use of TaqMan probe based chemistry was initially carried out with positive sequenced DWV and ABPV controls that were not included in the final results (Figure 2). In addition, before the evaluation for the presence of DWV and ABPV in selected samples started, concentrations of primers and probes were set at $0.8 \mu \mathrm{M}$ and $0.4 \mu \mathrm{M}$, respectively. The sensitivity of the method was investigated by testing 10-fold dilutions of two positive field samples for DWV and ABPV and comparing them to the results of the conventional RT-PCR. The detection limit was determined by the lowest dilution that showed specific amplification for the strong positive field samples selected as templates. Using the same positive samples, conventional RT-PCR had a dilution detection limit of $10^{-6}$ for both viruses, while the dilution detection limit for real-time RT-PCR was $10^{-8}$. TaqMan Ct values for DWV and ABPV in samples from locations Odzaci, Backa Palanka, Valjevo and Kladovo were mainly between Ct 25 and 30 (Figure 2). In the remaining locations where DWV and ABPV were recorded samples reached the threshold between 35 and 40 cycles.

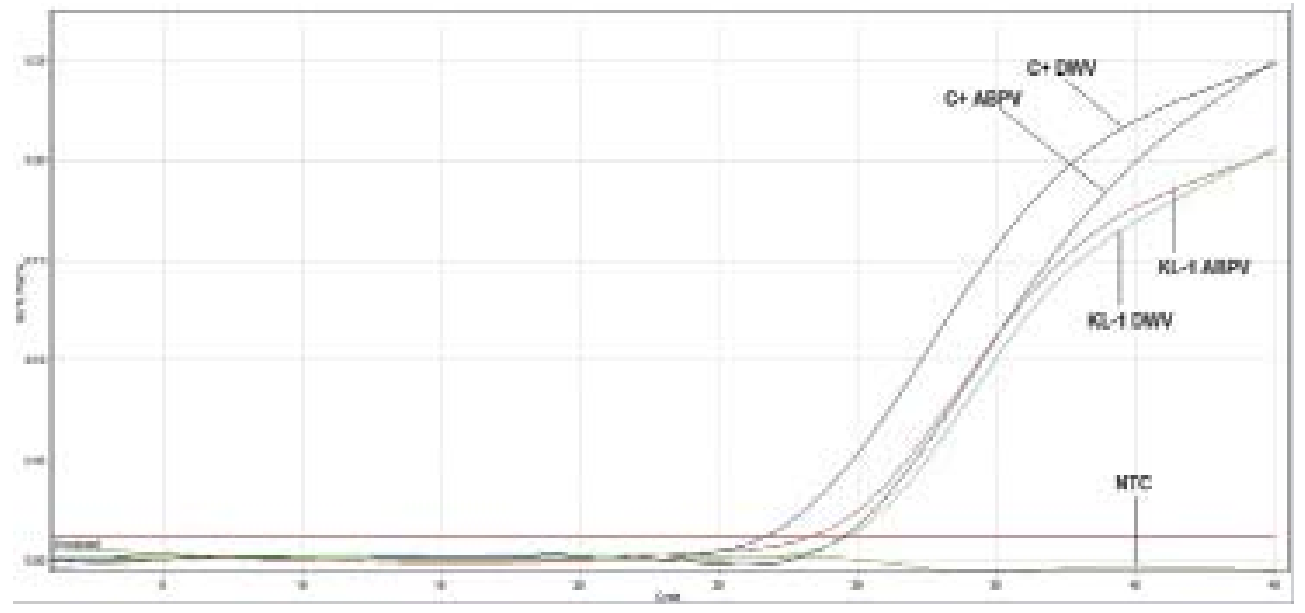

Figure 2 Amplification plot of a probe-based real-time RT-PCR assay showing DWV and ABPV positive bee samples. $\mathrm{C}+\mathrm{DWV}$ and $\mathrm{C}+\mathrm{ABPV}$ are representing positive controls for DWV and ABPV, respectively. KL1-DWV and KL1-ABPV are illustrating the presence of DWV and ABPV in samples from Kladovo. NTC stands for a no template control. Single replicates are shown for clarity, but each sample was tested in duplicate

\section{DISCUSSION}

This study reveals the presence and distribution of DWV and ABPV in Serbian apiaries. There are only two reports concerning the presence of bee viruses in samples originated from Serbia. The first one [45] is showing the existence of ABPV in Serbian honey bees. However, this investigation was conducted 23 years ago and in samples from a restricted area near Belgrade. In addition, methods used in that study were based on electron microscopy followed by immunodiffusion with no implication of molecular techniques. In the second one, Petrovic et al. [46] recorded the presence of both DWV and ABPV, but using conventional RT-PCR and only in apiaries from the northern part 
of Serbia. It is noteworthy that the applied methodology in both reports could not provide detection of low virus levels typical for persistent inapparent infections.

A total of 55 honey bee colonies distributed in different regions of Serbian territory were investigated by TaqMan probe-based real-time RT-PCR for the presence of DWV and ABPV, two important honey bee viruses implicated in colony mortality. In most of the apiaries where samples were collected, clinical signs of diseases concerning viral infections were lacking. In this study both monitored viruses were detected using real-time RT-PCR technique. The prevalence of positive DWV and ABPV samples in this survey is consistent with the results of Petrovic et al. [46] and reports from other countries. The finding of DWV in $76.4 \%$ of samples is within the range of $67-97 \%$ DWV-positive samples reported in other surveys $[12,13,15,18,46,47,50]$. The high prevalence of DWV in all sample locations is expected as an outcome of its close association with $V$. destructor, being the biological and mechanical vector for this virus. The sampling period also contributes to the obtained results, as climate conditions in Serbia during the sampling time still allow bees to forage forcing many beekeepers to postpone the autumn acaricide treatment. The results reported by Bailey et al.[4], Tentcheva et al. [12], Gauthier et al. [6] and Runckel et al. [51] show that ABPV is known to persist in apparently healthy colonies. The proportion of $61.8 \%$ samples positive to ABPV found in this study is in accordance with the estimates obtained in France (58\%) [12], Austria (68\%) [13], Hungary (37\%) [15], Germany (73\%) [33] and Slovenia (40\%) [47], but disagrees with findings of researchers in Denmark $(10.56 \%)$ [38], China (6\%) [18], South Korea (0\%) [52] and Uruguay (9\%) [50]. High prevalence of ABPV in Serbian samples could also be explained by the mite-virus relationship, sampling period and apitechnical measures mentioned earlier.

Although both DWV and ABPV were detected in Serbian apiaries, their occurrence and prevalence differ among sampling regions (Figure 1). Single DWV and ABPV infections in Serbia were present in $23.6 \%$ and $9.1 \%$ of samples, respectively; however, simultaneous DWV-ABPV infections were recorded in $50.9 \%$ of samples (Table 2). Simultaneous infections have been proven in asymptomatic colonies worldwide [53, $13,6,38,18]$. Infection with both viruses was recorded in each apiary from sampling locations in northern Serbia (Odzaci and Backa Palanka). High frequency of DWVABPV infection in northern Serbia could be connected with increased mite infection due to different control strategies directed against $V$. destructor among Serbian beekeepers. Namely, late forage in this region postpones $V$. destructor treatment with soft acaricides (e.g. thymol, formic and oxalic acids), raising the level of surviving mites and the possibility of virus spreading. In contrast, colonies from higher altitudes, such as Prijepolje and Ivanjica, where the hard acaricide treatment usually finishes by the end of July, had lower prevalence of DWV (60\% and 20\%, respectively) and ABPV ( $0 \%$ and $40 \%$, respectively) compared to other locations. Percentage of samples where neither of the monitored viruses was detected (Table 2) is higher than in reports of Tentcheva et al. [12], Berenyi et al. [13], Antúnez et al. [50], Toplak et al. [47] and Ai et al. [18], although several times lower in comparison with $64.4 \%$ virus-free samples from Spain [54]. This discrepancy could be explained by the number of viruses searched in each survey. 
Several RT-PCR assays $[6,12,13,55]$ or non-specific SybrGreen real-time RT-PCR $[33,37,56]$ have been designed for the purpose of the detection of DWV and ABPV. However, only few probe-based TaqMan real-time RT-PCR protocols have been published for DWV and ABPV [14,39]. Non-specific detection system is characterized by fluorescence enhancement upon binding the intercalating dye (SYBR Green) to dsDNA, while a specific probe is designed to bind within the amplified PCR fragment. Therefore, due to a non-specific binding to all dsDNA products, including primer dimers, SYBR Green detection system is usually less specific. In this study several TaqMan real-time RT-PCR reactions were conducted with positive and sequenced DWV and ABPV controls with the purpose of assay optimization (Figure 2). Unlike manufacturer's recommendations and protocol published by Chantawannakul et al. [14], we had to raise concentrations of primers and probes to $0.8 \mu \mathrm{M}$ and $0.4 \mu \mathrm{M}$, respectively, to reach the maximum sensitivity of the assay used in this study. In each sampling location where high prevalence of DWV and ABPV was recorded Ct values were mainly between $\mathrm{Ct} 25$ and 30, indicating high levels of these viruses in bee samples. Nevertheless, when sampling was conducted no signs of disease or colony collapse were observed. After serial 10-fold dilutions of strong positive DWV and ABPV field samples used to compare conventional and real-time RT-PCR assay, dilution detection limit of real-time RT-PCR was 100 times lower. This proved the higher sensitivity of real-time RT-PCR as reported by Jamnikar Ciglinečki et al. [39] and Blanchard et al. [57].

\section{ACKNOWLEDGMENTS}

This study was supported by the Ministry of Education, Science and Technological Development of the Republic of Serbia (Grant no. III 46002).

\section{REFERENCES}

1. Genersch E, Aubert M: Emerging and re-emerging viruses of the honey bee (Apis mellifera L.). Vet Res 2010, 41:54.

2. Chen YP, Siede R: Honey bee viruses. Adv Virus Res 2007, 70:33-80.

3. Genersch E, von der Ohe W, Kaatz H, Schroeder A, Otten C, Büchler R, Berg S, Ritter W, Mühlen W, Gisder S, Meixner M, Liebig G, Rosenkranz P: The German bee monitoring project: a long term study to understand periodically high winter losses of honeybee colonies. Apidologie 2010a, 41:332-352.

4. Bailey L, Ball BV, Perry JN: The prevalence of viruses of honey bees in Britain. Ann Appl Biol 1981, 97:109-118.

5. Evans JD, Hung AC: Molecular phylogenetics and the classification of honey bee viruses. Arch Virol 2000, 145:2015-2026.

6. Gauthier L, Tentcheva D, Tournaire M, Dainat B, Cousserans F, Colin ME, Bergoin M: Viral load estimation in asymptomatic honey bee colonies using the quantitative RT-PCR technique. Apidologie 2007, 38:426-435.

7. Highfield AC, El Nagar A, Mackinder LC, Laure MLN, Hall MJ, Martin SJ, Schroeder DC: Deformed wing virus implicated in overwintering honeybee colony losses. Appl Environ 
Microb 2009,75:7212-7220

8. Lanzi G, De Miranda JR, Boniotti MB, Cameron CE, Lavazza A, Capucci L, Camazine SM, Rossi C: Molecular and biological characterization of deformed wing virus of honeybees (Apis mellifera L.). J Virol 2006, 80:4998-5009.

9. Knowles NJ, Hovi T, Hyypiä T, King AMQ, Lindberg AM, Pallansch MA, Palmenberg AC, Simmonds P, Skern T, Stanway G, Yamashita T, Zell R: Picornaviridae. In: Virus Taxonomy: Classification and Nomenclature of Viruses: Ninth Report of the International Committee on Taxonomy of Viruses. Ed: King AMQ, Adams MJ, Carstens EB, Lefkowitz, EJ. San Diego: Elsevier; 2012, 855-880.

10. Adams MJ, Lefkowitz EJ, King AMQ, Carstens EB: Recently agreed changes to the statutes of the international committee on taxonomy of viruses. Arch Virol 2013, 1-6.

11. Nordström S: Distribution of deformed wing virus within honey bee (Apis mellifera) brood cells infested with the ectoparasitic mite Varroa destructor. Exp Appl Acarol 2003, 29:293302.

12. Tentcheva D, Gauthier L, Jouve S, Canabady- Rochelle L, Dainat B, Cousserans F, Colin ME, Ball BV, Bergoin M: Prevalence and seasonal variations of six bee viruses in Api smellifera $\mathrm{L}$. and Varroa destructor mite populations in France. Appl Environ Microb 2004, 70:7185-7191.

13. Berenyi O, Bakonyi T, Derakhshifar I, Köglberger H, Nowotny N: Occurence of six honeybee viruses in diseased Austrian apiaries. Appl Environ Microb 2006, 72:2414-2420.

14. Chantawannakul P, Ward L, Boonham N, Brown M: A scientific note on the detection of honeybee viruses using real-time PCR (TaqMan) in Varroa mites collected from a Tai honeybee (Apis mellifera) apiary. J Invertebr Pathol 2006, 91:69-73.

15. Forgách P, Bakonyi T, Tapaszti S, Nowotny N, Rusvai M: Prevalence of pathogenic bee viruses in Hungarian apiaries: situation before joining the European Union, J Invertebr Pathol 2008, 98:235-238.

16. Ribière M, Ball BV, Aubert M: Natural history and geographic distribution of honey bee viruses, in: Aubert M, Ball BV, Fries I, Moritz RFA, Milani N, Bernardinelli I: Virology and the honey bee, European Communities, Luxembourg: 2008, 15-84.

17. Williams GR, Rogers REL, Kalkstein AL, Taylor BA, Shutler D, Ostiguy N: Deformed wing virus in western honey bees (Apis mellifera) from Atlantic Canada and the first description of an overtly infected emerging queen. J Invertebr Pathol 2009, 101:77-79.

18. Ai H, Yan X, Han R: Occurrence and prevalence of seven bee viruses in Apismellifera and Apis cerana apiaries in China. J Invertebr Pathol 2012, 109:160-164.

19. Chen Y, Evans J, Feldlaufer M: Horizontal and vertical transmission of viruses in the honey bee, Apis mellifera. J Invertebr Pathol 2006, 92:152-159.

20. Forsgren E, de Miranda JR, Isaksson M: Deformed wing virus associated with Tropilaelaps mercedesae infesting European honey bees (Apis mellifera). Exp Appl Acarol 2009, 47:87-97.

21. Yue C, Schröder M, Bienefeld K, Genersch E: Detection of viral sequences in semen of honeybees (Apis mellifera): evidence for vertical transmission of viruses through drones. $\mathrm{J}$ Invertebr Pathol 2006, 92:105-108.

22. Yue C, Schröder M, Gisder S, Genersch E: Vertical transmission routes for deformed wing virus of honeybees (Apis mellifera). J Gen Virol 2007, 88:2329-2336.

23. de Miranda JR, Fries I: Venereal and vertical transmission of deformed wing virus in honey bees (Apis mellifera L.). J Invertebr Pathol 2008, 98:184-189. 
24. Möckel N, Gisder S, Genersch E: Horizontal transmission of deformed wing virus: Pathological consequences in adult bees (Apis mellifera) depend on the transmission route. $\mathrm{J}$ Gen Virol 2011, 92:370-377.

25. Yang X, Cox-Foster D: Effects of parasitization by Varroa destructor on survivorship and physiological traits of Apis mellifera in correlation with viral incidence and microbial challenge. Parasitology 2007, 134:405.

26. Bailey L, Ball BV: 1991. Honeybee pathology. Academic Press, London, United Kingdom.

27. Gisder S, Aumeier P, Genersch E: Deformed wing virus (DWV): viral load and replication in mites (Varroa destructor). J Gen Virol 2009, 90:463-467.

28. de Miranda J, Genersch E: Deformed wing virus. J Invertebr Pathol 2010, 103:48-61.

29. Allen MF, Ball BV: The incidence and world distribution of honey bee viruses. Bee World 1996, 77:141-162.

30. Ellis JD, Munn PA: The worldwide health status of honey bees. Bee World 2005, 86:88-101.

31. Hung ACF, Ball BV, Adams JR, Shimanuki H, Knox DA: A scientific note on the detection of American strains of acute paralysis virus and Kashmir bee virus in dead bees in one US honey bee (Apis mellifera L.) colony. Apidologie 1996, 27:55-56.

32. Békési L, Ball BV, Dobos-Kovács M, Bakonyi T, Rusvai M: Occurrence of acute paralysis virus of the honey bee (Apis mellifera) in a Hungarian apiary infested with the parasitic mite Varroa jacobsoni. Acta Vet Hung 1999, 47:319-324.

33. Siede R, König M, Büchler R, Failing K, Thiel HJ: A real-time PCR based survey on acute bee paralysis virus in German bee colonies, Apidologie 2008, 39:650-661.

34. Allen MF and Ball BV: Characterization and serological relationships of strains of Kashmir bee virus. Ann Appl Biol 1995, 126:471-484.

35. Anderson DL: A comparison of serological techniques for detecting and identifying honeybee viruses. J Invertebr Pathol 1984, 44:233-243.

36. Benjeddou M, Leat N, Allsopp M, Davison S: Detection of acute bee paralysis virus and black queen cell virus from honeybees by reverse transcriptase PCR. Appl Environ Microb 2001 67:2384-2387.

37. Kukielka D, Esperón F, Higes M, Sánchez-Vizcaíno JM: A sensitive one-step real-time RTPCR method for detection of deformed wing virus and black queen cell virus in honeybee Apis mellifera. J Virol Methods 2008, 147:275-281.

38. Nielsen SL, Nicolaisen M, Kryger P: Incidence of acute bee paralysis virus, black queen cell virus, chronic bee paralysis virus, deformed wing virus, Kashmir bee virus and sacbrood virus in honey bees (Apis mellifera) in Denmark. Apidologie 2008, 39:310-314.

39. Jamnikar Ciglenečki U, Toplak I: Development of a real-time RT-PCR assay with TaqMan probe for specific detection of acute bee paralysis virus. J Virol Methods 2012, 184:63-68.

40. de Miranda JR, Cordoni G, Budge G: The acute bee paralysis virus-Kashmir bee virusIsraeli acute paralysis virus complex. J Invertebr Pathol 2010, 10:30-47.

41. Stevanovic J, Stanimirovic Z, Genersch E, Kovacevic RS, Ljubenkovic J, Radakovic M, Aleksic N: Dominance of Nosema ceranae in honey bees in the Balkan countries in the absence of symptoms of colony collapse disorder. Apidologie 2011, 41:49-58.

42. Stevanovic J, Simeunovic P, Gajic B, Lakic N, Radovic D, Fries I, Stanimirovic Z: Characteristics of Nosema ceranae infection in Serbian honey bee colonies. Apidologie 2013, 44:522-536. 
43. Stanimirović Z, Aleksić N, Stevanović J, Ćirković D, Mirilović M, Đelić N, Stojić V: The influence of pulverised sugar dusting on the degree of infestation of honey bee colonies with Varroa destructor. Acta Vet-Beograd 2011, 61:309-325.

44. Gajic B, Radulovic Z, Stevanovic J, Kulisic Z, Vucicevic M, Simeunovic P, Stanimirovic Z: Variability of the honey bee mite Varroa destructor in Serbia based on mtDNA analysis. Exp Appl Acarol 2013, 61:97-105.

45. Kulinčević J, Ball B, Mladjan V: Viruses in honey bee colonies infested with Varroa jacobsoni: first findings in Yugoslavia. Acta Vet-Beograd 1990, 40:37-42.

46. Petrovic T, Vidanovic D, Stojanov I, Lupulovic D, Lazic G: First molecular detection of six honeybee viruses in Serbian apiaries. Proceedings, 10th International Symposium Modern Trends in Livestock Production, Belgrade, 2 - 4 October, 2013, Institute for Animal Husbandry, Belgrade 2013, 627:639.

47. Toplak I, Rihtarič D, Ciglenečki UJ, Hostnik P, Jenčič V, Barlič-Maganja D: Detection of six honeybee viruses in clinically affected colonies of Carniolan gray bee (Apis mellifera carnica). Slov Vet Res 2012, 49:89-96.

48. Mackay, IM: Real-time PCR in the microbiology laboratory. Clin Microbiol Infec 2004, 10:190-212.

49. ANSES: French Agency for Food, Environmental and Occupational Health \& Safety Screening for several honeybee viruses using PCR (in-house method) (ABPV, IAPV, KBV, DWV, SBV, BQCV, CBPV). 2011, http://www.anses.fr/en.

50. Antúnez K, D’Alessandro B, Corbella E, Ramallo G, Zunino P: Honeybee viruses in Uruguay. J Invertebr Pathol 2006, 93:67-70.

51. Runckel C, Flenniken ML, Engel JC, Ruby JG, Ganem D, Andino R, DeRisi JL: Temporal analysis of the honey bee microbiome reveals four novel viruses and seasonal prevalence of known viruses, Nosema, and Crithidia. PLoS One 2011, 6:e20656.

52. Choe SE, Nguyen LTK, Noh JH, Koh HB, Jean YH, Kweon CH, Kang SW: Prevalence and distribution of six bee viruses in Korean Apis cerana populations. J Invertebr Pathol 2012, 109:330-333.

53. Chen Y, Zhao Y, Hammond J, Hsu HT, Evans J, Feldlaufer M: Multiple virus infections in the honey bee and genome divergence of honey bee viruses. J Invertebr Pathol 2004, 87:8493.

54. Antúnez K, Anido M, Garrido-Bailon E, Botias C, Zunino P, Martínez-Salvador A, Higes M: Low prevalence of honeybee viruses in Spain during 2006 and 2007. Res Vet Sci 2012, 93:1441-1445.

55. Grabensteiner E, Ritter W, Carter MJ, Davison S, Pechhacker H, Kolodziejek J, Boecking O, Derakshhifar I, Moosbeckhofer R, Licek E, Nowotny N: Sacbrood virus of the honeybee (Apis mellifera): rapid identification and phylogenetic analysis using reverse transcriptionPCR. Clin Diagn Lab Immun 2001, 8:93-104.

56. Kukielka D, Sánchez-Vizcaíno JM: One-step real-time quantitative PCR assays for the detection and field study of Sacbrood honeybee and Acute bee paralysis viruses. J Virol Methods 2009, 161:240-246.

57. Blanchard P, Ribière M, Celle O, Lallemand P, Schurr F, Olivier V, Iscache AL, Faucon JP: Evaluation of a real-time two-step RT-PCR assay for quantitation of Chronic bee paralysis virus (CBPV) genome in experimentally-infected bee tissues and in life stages of a symptomatic colony. J Virol Methods 2007, 141:7-13. 


\section{ISPITIVANJE PRISUSTVA VIRUSA DEFORMACIJE KRILA I VIRUSA AKUTNE PARALIZE PČELA U PČELINJIM ZAJEDNICAMA IZ SRBIJE UPOTREBOM "REAL-TIME RT-PCR" METODE}

SIMEUNOVIĆ Predrag, STEVANOVIĆ Jevrosima, VIDANOVIĆ Dejan, NIŠAVIĆ Jakov, RADOVIĆ Dejan, STANIŠIĆ Ljubodrag, STANIMIROVIĆ Zoran

Ovo istraživanje je obuhvatilo utvrđivanje prisustva virusa deformacije krila (DWV) i virusa akutne paralize pčela (ABPV) u 55 pčelinjih društava poreklom iz različitih delova teritorije Srbije, upotrebom "real-time RT-PCR" metode bazirane na "TaqMan" probama. Rezultati pokazuju prisustvo DWV na svakom ispitivanom lokalitetu, dok je ABPV bio prisutan u 10 od 11 ispitivanih pčelinjaka. Imajući u vidu ulogu ektoparazita Varroa destructor u prenošenju i aktivaciji pčelinjih virusa, visoka učestalost uzoraka pozitivnih na DWV $(76,4 \%)$ i ABPV $(61,8 \%)$ u asimptomatskim pčelinjim društvima može biti posledica nedovoljno efikasnog i zakasnelog tretmana protiv ove grinje. "Realtime RT-PCR" metoda, opisana u ovom radu se pokazala kao najpogodnija metoda za ovakvu vrstu istraživanja. 